\title{
2. A law and economics approach to cost shifting, fee arrangements and legal expense insurance Louis Visscher and Tom Schepens
}

\section{INTRODUCTION}

In this chapter, we will provide an overview of the economic literature regarding cost shifting, fee arrangements and legal expense insurance. In the economic analysis of law, legal rules are regarded as instruments which can provide actors with behavioural incentives. In essence, private law (torts, contracts, property, etc.) allocates the costs which arise out of different activities. Those costs may only be borne by the party causing them if the party initially suffering from them brings suit. Problems in financing civil litigation may effectively hinder such lawsuits, so that the behavioural incentives which the law intends to provide do not reach the party causing the harm.

For example, tort law is regarded as an instrument that induces people to take care. The prospect of being held liable after negligently having caused losses may induce a potential tortfeasor to take due care, because taking due care (thereby avoiding liability) is less costly than taking too little care (and being liable). Contract law is seen as a device that enables people to increase welfare by engaging in voluntary transactions. The remedies of contract law (specific performance and damages) induce the debtor to fulfil his contractual duties when this is less costly than breaching the contract and facing the sanction. If the victim of a tort or the creditor in a contractual setting does not bring a claim against the tortfeasor or the debtor, neither the tortfeasor nor debtor would face any expected sanction. This would not confront them with the costs they have caused and hence they would not receive the desired incentives. After all, in deciding how to behave, rational actors do not look at the costs they may cause, but only at the costs they may have to bear (Schäfer 2000, p. 184).

Many reasons exist that explain why actors such as the victim of a tort or the creditor in a contract may not effectuate their claim. The first 
reason, which forms the topic of this chapter, is that the costs of bringing a claim may outweigh the expected benefits. In such cases, a rational victim would decide not to effectuate the claim, because that would cost more than it yields in expected benefits. In economic terms, the victim stays rationally apathetic (This concept was introduced by Downs (1957). Also see Schäfer 2000, p. 184). Besides rational apathy, other reasons exist for why actors may not bring suit. They might not know that a law infringement has occurred to which they can react. In a typical tort setting, the victim often knows that he has been injured, and he knows the injurer or the costs of identifying the injurer are low (Landes and Posner 1975, p. 31). With infringements of safety regulations, for example, this may be different. It may be difficult for individual victims to recognize unsafe products, and violations of safety standards might go undetected until harm occurs. Even after harm has materialized, it may prove to be difficult for the individual victim to prove violation of the relevant safety rules (Van den Bergh and Visscher 2008, p. 40). The burden of proof constitutes another reason why victims do not always bring a claim. If they assess that they will not be able to prove negligence, causation, legally relevant losses, et cetera, they could very well decide not to start a procedure, given that they do not expect to prevail. Finally, strategic behaviour may bar claims from being brought. If the victim is not the only one who suffered losses, he may try to take a free ride on the efforts of other victims. If a group of people suffers from, for example, noise or smell from a nearby factory, an action for an injunction would benefit all victims. Each individual victim prefers someone else to bear the costs of the lawsuit, because after a successful procedure, he will also benefit from the injunction. If too many victims behave as free riders, the necessary law suit may not be brought in the first place, leaving all victims worse off.

We will focus our attention on the issue of rational apathy. We will analyze three possible ways to overcome this problem: cost shifting, fee arrangements and legal expense insurance. All of these approaches shift (some of) the costs of civil litigation to party other than the plaintiff. Cost shifting entails that (part of) the litigation costs of a successful plaintiff are transferred to the defendant. Fee arrangement lead to the result that the plaintiff only bears attorney costs if he wins. Legal expense insurance shifts the costs to the insurer, in exchange for a premium. By lowering the financial hurdles of bringing a claim, all instruments may provide solutions to the problem of financing civil litigation, thereby improving the behavioural incentives that the legal system can provide. This may ultimately even lead to fewer cases being tried because fewer violations occur (Miceli and Segerson 1991, Katz 2000, p. 76 ff.).

The aim of this chapter is to provide an overview of the economic 
literature dealing with these instruments. We believe this literature provides valuable insights which help to assess the potential of and the limits to these instruments to overcome or decrease the rational apathy problem. This is obviously very relevant for a volume which discusses new trends in financing civil litigation from a legal, empirical and economic point of view.

We will analyze the possible impact of cost shifting, fee arrangements and legal expense insurance not only on the number of suits being brought, but on all stages in the dispute resolution process: (1) filing a claim, (2) possibly dropping the claim due to new information, (3) settlement negotiations and (4) adjudication. We investigate the impact of the various instruments by comparing them with the situation where the plaintiff himself bears the costs. In Section 2 we briefly describe the dispute resolution process and indicate the economic decision-making process in each stage. In Section 3 we analyze the impact of cost shifting, more specifically applying the so-called English Rule instead of the American Rule. In Section 4 we investigate the influence of fee arrangements by comparing a system of hourly fees with a system of contingency fees. In Section 5 we analyze the impact of legal expense insurances in each stage of the dispute resolution process. In Section 6 we summarize and conclude.

\section{THE DISPUTE RESOLUTION PROCESS}

The economic theory of litigation was developed in the early 1970s'. It still serves as the standard model and also constitutes the basis of our approach (Landes 1971, Gould 1973, Posner 1973. Also see Cooter and Rubinfeld 1989, Kobayashi and Parker 2000, Shavell 2004, pp. 389-418).

The economic theory of litigation does not only encompass the different stages of dispute resolution, but also the stage before a dispute has even arisen. In other words, the phase in which actors decide how to behave is also included in the analysis. It is assumed that actors behave rationally. That is, they are assumed to maximize their expected utility, given their beliefs and their available information. Hence, the behaviour in the first stage of the model depends on a weighing of expected costs and benefits. Expected liability is a relevant factor in this weighing process. By taking adequate care, by fulfilling contractual obligations, et cetera, parties can reduce the probability of being held liable or they can avoid liability altogether. The level of expected liability and hence the expected utility of the potential wrongdoer is influenced by whether or not the potential victims respond to an infringement. If they remain rationally apathetic, the potential wrongdoer faces no expected liability. This provides him with 
inadequate behavioural incentives, compared to the social optimum where he incorporates the effects of his behaviour on others.

At the second stage, the plaintiff, who in the first stage suffered losses due to the behaviour of the defendant, decides whether or not to file a claim. This stage is called the filing stage. It is important to note that the filing stage encompasses both formal and informal ways of bringing a claim. Shavell describes it as follows: 'Bringing suit is interpreted as any action which results ultimately in settlement or in trial. Thus, we would consider a mere threat to initiate formal proceedings as a suit if the threat resulted in a settlement' (Shavell 1982, 56 nt. 5). Given that filing a claim costs time and/or money, a plaintiff will only do so if he has a credible threat to go to trial. Generally speaking, this is the case if the expected value of the claim (the expected judgment, multiplied by the probability of prevailing) exceeds the expected costs. Such cases are referred to as positive net expected value claims. In the absence of such a credible threat, the potential defendant does not fear trial and does not incorporate expected liability into his decisions. However, it is recognized in the literature that negative expected value suits may also be brought if they can induce the defendant to settle (Bebchuck 1996, Kobayashi and Parker 2000, p. 14). This could happen if, for example, the defendant's costs of going to trial outweigh the costs of settlement, even if the defendant is certain to prevail in court. We will not incorporate this situation in our analysis.

After a plaintiff has filed a claim, new information which influences the expected outcome may become available. If a claim that previously seemed to have a positive net expected value, after incorporation of the new information turns out to have a negative expected value, the plaintiff may decide to drop it in the third stage of the dispute resolution process. For example, the plaintiff's losses may be lower than he originally assessed, so that the expected damages if successful also decrease. It is also possible that the new information becomes available at another stage of the whole procedure, for example after the defendant refuses to offer to settle (P'ng 1983, p. 540, P'ng 1987, pp.62-63. Also see Kobayashi and Parker 2000, p. 14). In this chapter, however, we only deal with a drop stage between filing the claim and engaging in settlement negotiations.

In phase four, settlement negotiations may take place. Due to the high costs, risks and duration of going to trial, parties may prefer to settle their dispute. If both parties would be better off by settling, there exists a settlement surplus, resulting in a positive settlement range. The plaintiff would be better off if the settlement exceeds the expected outcome of trial minus the expected litigation costs he has to bear. The defendant would be better off if the settlement amount falls short of the expected judgment at trial plus the expected litigation costs he has to bear. The settlement surplus 
equals the sum of both parties' litigation costs minus the amount by which the plaintiff's estimation of the expected judgment exceeds the defendant's estimation (Cooter and Rubinfeld 1989, p. 1075). For example, if the plaintiff assesses the outcome of trial at 100, the defendant at 80 and the litigation costs would amount to 25 for each party, the settlement surplus is $(25+25-20)=30$. The plaintiff would be better off if the settlement exceeds $(100-25)=75$, and the defendant if the settlement is less than $(80+25)=105$. The difference of 30 between both limits is the settlement surplus. The settlement range runs from 75 to 105 . Whether or not a settlement will actually be reached depends on the information both parties possess and on the bargaining process, where the possibility of strategic behaviour is important (P'ng 1983, Shavell 1982, Hay and Spier 1998, Daughety 2000). The chance that a settlement is reached, increases with the size of the settlement surplus.

If the parties do not reach a settlement, the case proceeds to the fifth stage: trial. Each party will spend rationally on litigation up to the point where an additional investment no longer improves the expected outcome by more than the additional costs. The optimal expenditure for each party is found there, where its marginal costs equal its marginal benefits.

\section{COST SHIFTING}

\subsection{Introduction}

Different arrangements regarding litigation costs exist. Under the socalled English Rule, the prevailing party recovers some or all litigation costs from the unsuccessful party. In contrast, under the American Rule, each party bears its own expenses. In order to be able to fully focus on the impact of cost shifting, in this section we compare the English Rule, where all costs are shifted, with the American Rule and disregard the more complicated intermediary possibilities where only some costs are shifted. The theoretical effects we distinguish in the analysis below will in practice be less pronounced if not all costs are shifted.

\subsection{Trial Expenditure}

In economic literature, it is argued that trial expenditure will be greater under the English Rule than under the American Rule (Brauetigam, Owen and Panzar 1984, pp. 180-181, Katz 1987, p. 159 ff., Hause 1989, p. 166). After all, given that under the English Rule the unsuccessful party has to bear the litigation costs of the prevailing party (so that there is more at 
stake), the marginal benefits of additional investment in trial expenditure outweigh those under the American Rule. It is optimal to invest until the marginal costs equal the marginal benefits, and due to the higher marginal benefits this point is reached later under the English Rule. In addition to the higher marginal benefits, the marginal costs are lower under the English Rule, because parties only expect to bear litigation costs if they lose the trial.

It is difficult to isolate this effect empirically. Hughes and Snyder have studied the introduction of the English Rule to medical malpractice claims during the period 1980-85 in Florida. This research reports an increase in defence expenditure of 108 per cent for litigated claims and 150 per cent for settled claims (Hughes and Snyder 1998, p. 51). Kritzer, however, argues that it is hard to isolate the impact of fee arrangements. He states that 'this does not mean that fee arrangements do not matter; rather, it is indicative of the complexity of the effects of fee arrangements. The various effects tend to cross-cut in significant ways. The result is often that clear evidence of effects is difficult to find' (Kritzer 2002, p. 1983).

\subsection{Level of Suit}

The likely effect of cost shifting on the level of suits depends on several interrelated factors. These effects are most clearly shown when compared to the benchmark where the cost-allocation rule does not matter: the plaintiff assesses his probability of winning at 50 per cent; both parties are expected to spend the same amount on litigation; the English Rule does not lead to greater trial expenditures and both parties are risk neutral. By subsequently changing one of these four conditions, its effect on the level of suit can be assessed.

The first issue is the plaintiff's assessment of his chance of prevailing. The higher his estimated probability of success, the higher the expected benefits of the suit. The expected value of the claim (net of litigation costs) therefore increases with the probability of success, which results in a higher willingness to sue (Shavell 1982, pp. 59-60. Also see Rickman 1995, p. 331). This effect is stronger under the English Rule, because under the American Rule a successful plaintiff still has to bear his own litigation costs.

The second relevant factor is how much both parties are spending on litigation. All other things being equal, if the plaintiff expects to outspend the defendant, he is more likely to bring suit under the English Rule than under the American Rule. After all, given the estimated probability of success of 50 per cent, under the English Rule the plaintiff expects to have to bear half of both parties' costs, which by definition (due to the 
outspending) is less than having to bear his own costs fully under the American Rule (Hause 1989, pp.167-168, Snyder and Hughes 1990, p. 349). The opposite result holds if the plaintiff expects to be outspended by the defendant.

The third factor relates to Section 3.2 above. There it became clear that parties are expected to spend more on litigation under the English Rule. This greater expenditure lowers the claim's expected value, which results in a lower level of suit as compared to the American Rule (Hause 1989, pp. 167-168, Snyder and Hughes 1990, p. 351, 352).

Finally, the risk attitude of parties matters. A risk neutral actor is only concerned with the expected value of a certain project and not with the possible magnitude of the outcome. (S)he therefore is indifferent between a project with a certain outcome of $€ 100$ and a project with a 50 per cent probability of $€ 200$. A risk-averse actor on the other hand is also concerned with the possible magnitude of the outcome and prefers the certainty of $€ 100$ over the 50 per cent possibility of $€ 200$. This risk attitude is caused by the decreasing marginal utility of wealth, due to which a loss in wealth leads to a more than proportional loss in utility. The plaintiff's risk aversion leads to a lower level of suit, given that litigation entails uncertainty. This effect is stronger under the English Rule than under the American Rule, because the consequences of winning or losing are larger (Shavell 1982, pp.61-62). The greater expenditures effect of the English Rule reinforces this.

The four effects are interrelated and depend on the circumstances of the case. It is therefore not possible to determine a general overall effect on the level of suit of a shift from the American to the English Rule.

\subsection{Quality of the Claims}

The first effect of a shift to the English Rule that we have described in Section 3.3 encourages the filing of high-merit claims. After all, the higher the probability of success, the lower the probability of having to bear the litigation costs under the English Rule, whereas under the American Rule the plaintiff would still bear his own costs. This effect is very clear in the extreme situation of certainty of winning the case. Under the American Rule, the plaintiff still has to bear his litigation costs, and hence refrains from filing the claim if its value is lower than these costs, even if he is certain to win. Under the English Rule he would file the claim, because he is certain that he does not bear the litigation costs himself (Shavell 1982, p. 59, Rosenberg and Shavell 1985, pp. 5-6). However, the second effect we have described in Section 3.3 (outspending) may mitigate the encouragement of high-merit claims under the English Rule: in case the defendant 
sufficiently outspends the plaintiff low value claims are discouraged, even if they are of high merit. The third effect (greater expenditures) and introduction of risk aversion may also hinder the encouragement of strong but small claims under the English Rule (Hause 1989, pp. 167-168, Snyder and Hughes 1990, p. 349 ff.).

Cost-shifting discourages the filing of weak claims, because the probability that the plaintiff who files a weak claim also has to bear the litigation costs of the defendant is relatively high. The greater expenditures effect, risk aversion and outspending by the plaintiff reinforce this discouragement.

Hence, the English Rule entails a selection effect in favour of high merit claims, even of relatively low value. This effect is, however, mitigated by greater expenditures, increased risk and possible outspending by the defendant. Due to these mitigating effects, there is a critical probability of success and a critical value of the claim below which the plaintiff will not sue. This leads to a selection effect in the direction of high merit and high value claims (Snyder and Hughes 1990, p. 349). Empirical research indeed suggests that the probability for plaintiffs to prevail increases under the English Rule (Hughes and Snyder 1995, p. 238).

It should be noted that if a plaintiff is judgment proof so that he cannot pay the litigation costs of the defendant in the case of losing the trial, he may also file weaker claims (Di Pietro, Karns and Kelley 1995, p. 101). Furthermore, the plaintiff's subjective assessment of the merits of the claim determines his behaviour. Given that under the English Rule he may have to bear the litigation costs of both parties, he will have an incentive to screen claims more carefully (Mause 1969, p. 32).

\subsection{Drop Rate}

Whether a plaintiff drops a claim depends on his assessment of the expected value of the claim. Given the quality enhancing features of the English Rule, which were discussed above, one would expect a lower drop rate than under the American Rule. Fewer low quality claims, which may eventually reach the drop stage, are brought under the English Rule in the first place. However, whether or not a claim is dropped ultimately depends on the type of information that becomes available after the claim is brought and, more in particular, the way in which the information affects the claim's expected value under either one or both rules. It is theoretically impossible to know what information will become available. Therefore, it is also impossible to predict the overall effect on the drop rate.

Despite the theoretical impossibility of predicting the overall effect, there is empirical research that found an increase in the drop rate of 10.4 
per cent (Snyder and Hughes 1990, p.364). This may be explained by the low filing costs: plaintiffs file a claim without carefully ascertaining its quality, with the purpose of acquiring more information (Snyder and Hughes 1990, p.377). The claim selection characteristic of the English Rule apparently occurs at the drop stage rather than at the filing stage.

\subsection{Settlement Rate}

When the literature on the effects of the English Rule on settlement behaviour is analyzed, it becomes clear that no unambiguous results exist. Given that the English Rule increases litigation expenditure, it increases the settlement surplus. Settlement hence becomes more attractive because it can avoid higher litigation costs (Bowles 1987, p. 177 ff., Hause 1989, p. 167). Risk aversion strengthens this tendency, because by settling, parties can avoid the risky trial (Shavell 1982, p. 68).

On the other hand, in as far as parties have a tendency to overestimate their probability of success, the English Rule leads to fewer settlements. Over optimism reduces the settlement surplus because it increases the difference in the parties' expectations of the outcome of the trial. The English Rule strengthens this effect because the over optimism also extends to the litigation costs (Shavell 1982, pp. 65-66, Katz (1987), p. 157 ff).

The overall effect of cost shifting on the settlement rate cannot be determined theoretically, because it depends on the relative size of the two distinguished effects. Empirical research suggests that the over optimism effect dominates, for it has found a decrease in the settlement rate of 9.6 per cent (Snyder and Hughes 1990, p. 366).

\subsection{Level of Adjudication}

All the above-described effects determine the overall influence of cost shifting on the level of adjudication. It is impossible to draw general conclusions on this issue on a theoretical level. Empirical research found that the probability for a filed claim to be adjudicated decreased by 5 per cent as a result of the English Rule. This effect consists of a decrease of 9.4 per cent due to the selection effect, which leads to a higher drop rate on the one hand, and an increase of 4.4 per cent due to less settlements as a result of over optimism on the other hand (Snyder and Hughes 1990, p. 364 ff.).

\subsection{Duration of Claims}

The decision whether or not to drop a claim is made on the basis of its expected value. As soon as this value becomes negative, the claim will be 
dropped. New information leading to a lower estimation of the merits of the claim under the English Rule also increases the assessed probability of having to bear the other party's litigation costs. Hence, the expected value decreases more quickly under the English Rule as such information becomes available, leading to an earlier drop than under the American Rule. The greater expenditure effect strengthens this tendency (Hughes and Savoca 1997, p.264). Empirical findings corroborate this view (Hughes and Savoca 1997, p. 269).

The English Rule also shortens the duration of the settled claims. Due to the selection effect, the claims that proceed to the settlement stage are, on average, of higher quality. If parties indeed settle, the over optimism effect has turn out not to be prohibitively large. Under these conditions, the plaintiff has a credible threat to go to trial, and given the relatively high quality of the case, the defendant faces a good possibility of having to bear all litigation costs. It is therefore in his best interest to quickly settle the case (Hughes and Savoca 1997, pp. 264-265, 269).

The adjudication phase, finally, is expected to take longer under the English Rule, due to the greater expenditures effect. The possibility of having to pay the other party's litigation costs does not counter this effect, because parties are overly optimistic about their prospects (otherwise, they would have already dropped or settled the claim). Each party hence expects that the other party will have to bear the litigation costs (Hughes and Savoca 1997, p. 294).

\section{FEE ARRANGEMENTS}

\subsection{Introduction}

Lawyer's fees constitute a large part of the costs of pursuing a legal claim (see for example Williams and Williams 1994, p. 79 ff.). Broadly speaking, besides fixed fees, two forms of payment for legal services exist: hourly fees and contingency fees. Under hourly fees, the party hiring the attorney has to pay the fee, regardless of the outcome of the case. Under contingency fees, on the other hand, the lawyer's reward often depends on two contingencies. First, if the case is lost, the lawyer receives no compensation ('no cure, no pay'). Second, if the case is won, the fee is often a prefixed percentage of the obtained award ('quota pars litis').

In many European countries, contingency fees are prohibited, whereas in the United States these are commonly used (also see Chapter 3 by Faure, Fernhout and Philipsen and Chapter 8 by Hensler). Article 3.3 of the Code of Conduct for Lawyers in the European Union explicitly states that 'A 
lawyer shall not be entitled to make a pactum de quota litis'. However, the traditional European resistance seems to be weakening. In the United Kingdom, conditional fees were adopted in the 1990s. The main difference between contingent and conditional fees is the idea of quota pars litis, which is not present under conditional fees. Under such conditional fees the lawyer receives a premium (not related to the amount at stake) if the case is won and nothing if the case is lost. According to Emons, in Belgium and the Netherlands such conditional fees also exist. Furthermore, 'Spain, France, Italy, and Portugal are considering the introduction of conditional fees. Germany has also relaxed some restrictions by means of third party contingent contracts (. . .). In Greece contingent fees of up to 20 per cent as well as conditional fees are permitted' (Emons 2007, pp.89-90. See Faure, Hartlief and Philipsen 2006a and 2006b and Chapter 3 in this book for an overview of conditional fees in several European countries and Hong Kong).

In this section, we will analyse hourly fees and contingency fees from an economic point of view. Both the dispute resolution model as well as the principal-agent theory is relevant in this respect. Both will be subsequently discussed.

\subsection{Level of Suit}

In the literature it is generally argued that contingency fees lead to an increase in the level of suit. The first reason, which lies at the core of this chapter and even the entire book, is the fact that contingency fees can be used to finance the attorney costs of pursuing a claim. After all, the costs are only paid after a positive result has been achieved. In essence, the plaintiff borrows money from his lawyer while the case is pending. This allows him to bring suit also in cases where an hourly wage might have been prohibitively costly.

Second, contingency fees essentially contain an insurance policy which shifts the risk of not obtaining a sufficient award to cover the attorney costs from the plaintiff to the lawyer. Risk-averse plaintiffs will hence be less often deterred from bringing a claim, because their financial risk is lower under contingency fees (Posner [1973] 2003, p. 584). Given that lawyers can diversify their portfolio of cases, they are likely to be less risk averse than their clients. This reduces the overall costs of risk borne by the plaintiffs and lawyers. Hourly fees do not allow for such beneficial risk sharing (Gravelle 1998, p. 383).

Whether or not these two effects lead to an overall increase in the level of suit depends on the existence of overcapacity in the market for legal services. If there is no excess capacity and lawyers in some cases shift 
from hourly wages to contingency fees, the total number of cases would decrease if they spend more time on these contingency fee cases than they would have spent under a system of hourly fees. There is (limited) empirical literature suggesting that contingency fee lawyers spend fewer hours on small cases than hourly fee lawyers, but more hours on cases with a higher value (Kritzer et al. 1985, pp. 266-267).

The percentage that is agreed upon in the contingency fee arrangement determines the share of the judgment that the plaintiff receives after deduction of the lawyer's fee. In his decision of whether or not to bring suit, the plaintiff compares his expected benefits with the other costs involved in litigation, which he still bears himself. After all, contingency fees only regard the attorney fee. The agreed percentage itself therefore also influences the level of suit. On the one hand, the higher this percentage the less often a plaintiff will bring suit because the expected benefits decrease. On the other hand, in as far as a higher percentage induces the attorney to devote more effort to the case (see Section 4.5 below), the probability of winning and/ or the magnitude of the award may increase, leading to higher expected benefits. The overall effect cannot be predicted theoretically.

\subsection{Quality of the Claims}

It is often argued that contingency fees encourage meritless litigation, because the plaintiff does not bear the risk of having to pay the attorney fee if he loses. Hence, under the simplifying assumption that there are no litigation costs besides the attorney fee (which better allows us to focus on the difference between hourly fees and contingency fees), the plaintiff would be willing to start a claim as soon as there is a positive probability of success, no matter how small.

However, this line of reasoning overlooks the crucial role of the attorney. He will only be interested in trying the case if there is a large enough probability of winning, because only then will he receive the agreed percentage (Dana and Spier 1993, pp.349-350, Miceli 1994). Given that a lawyer is a repeat player who ordinarily can better assess the quality of a case than the plaintiff, he will also be better able to screen cases and distinguish the low-quality from the high-quality cases. In that sense, contingency fees are expected to increase the overall quality of the cases being brought (Clermont and Currivan 1978, pp. 571-572). Empirical research verifies this gate-keeping role of lawyers working on a contingency fee basis, but it also shows that lawyers turn down cases with a relative low value (Kritzer 1997, p. 26 ff.). A report on the profitability of conditional fees in the United Kingdom suggests that specialization as well as screening cases on their probability of success has a positive impact on the profits 
of a firm (KPMG 1998). Other research indicates that under a system of hourly fees lawyers have fewer incentives to provide the plaintiff with an unbiased assessment of the quality of their claim than contingency fee lawyers (Dana and Spier 1993).

\subsection{Drop Rate}

Given that the remuneration of a contingency fee lawyer depends on the outcome of the case, we can expect him to screen information that becomes available after the suit was brought more carefully than hourly fee lawyers. In deciding whether or not to continue the case, the contingency fee lawyer requires a sufficiently high expected return. This so-called screening effect leads to more cases being dropped under contingency fees.

However, there is an opposite selection effect, which is caused by less screening by hourly fee lawyers in the filing stage, which was discussed in Section 4.3. Hourly fee lawyers have fewer incentives to avoid low quality claims from being filed so more of such claims reach the drop stage. The probability that clients will decide to drop a claim as a result of new information suggesting a negative expected value is therefore higher under hourly fees than under contingency fees.

Theoretically it is impossible to predict the overall effect of contingency fees on the drop rate. Danzon and Lillard (1983, p. 363) in their empirical research found that the selection effect outweighs the screening effect. Limitations on contingency fees lead to an increase in the drop rate of 5 per cent.

\subsection{Settlement Rate}

Different strands of literature provide different predictions regarding the impact of contingency fees on the settlement rate. In the first strand it is argued that contingency fees lead to more settlements, because this way the lawyer secures his share of the settlement without having to invest additional time and effort. Given that the lawyer is interested in his share of the settlement rather than in the client's share, he may advise to settle for an amount that is too low, as this increases the likelihood that the defendant accepts the settlement offer (see for example Schwartz and Mitchell 1970, Miller 1987, Thomason 1991 and Gravelle and Waterson 1993).

The second strand of literature incorporates the effect of fee arrangements on attorney effort. Contingency fee lawyers in essence weigh their costs of additional efforts against the expected increase in their own reward, which is only a fraction of the total benefits of increased efforts. 
This induces them to spend less time on a tried case than is in the best interest of their client. Only if the contingency fee percentage is 100 per cent (hence, if the lawyer buys the claim from his client), would this problem be avoided. This, however, is prohibited in most US states (Santore and Viard 2001). Incorporating this effect on attorney effort, the expected cost of the defendant of going to trial is lower, making it less likely for him to accept any given settlement demand. The costs of the plaintiff's attorney of going to court are also lower because he spends less than optimal efforts on it. This can result in the contingency fee lawyer proposing a settlement offer that is too high, resulting in fewer settlements, so that the case goes to trial (Polinsky and Rubinfeld 2002, p. 222 ff. Also see Miceli 1994, Bebchuk and Guzman 1996 and Rickman 1999).

Empirical evidence corroborates the findings of the second strand of literature. The settlement rate turns out to increase if limits on contingency fees are introduced, and the settlement amounts decrease (Danzon and Lillard 1983, p. 363, Snyder and Hughes 1990, p. 366).

\subsection{Level of Adjudication}

In the previous sections, we have seen that under hourly fees the drop rate of claims as well as the number of settled cases is higher than under contingency fees. Hence, relatively fewer claims are adjudicated under hourly fees. It is also shown empirically that limitations on contingency fees tend to decrease the probability that a claim proceeds to trial (Snyder and Hughes 1990, p.360).

\subsection{Duration of Claims}

When discussing the drop rate, we saw that under contingency fees the lawyer is the primary decision taker, whereas under hourly fees it is the client. Both want to avoid spending resources on a case with an expected value that is too low. Given the superior information of the lawyer in this respect, we expect filed cases to be dropped sooner under contingency fees. We do not know of any empirical studies regarding this specific issue.

Regarding the settlement phase, a contingency fee lawyer does not gain by prolonging the negotiations any further than necessary, because he does not gain by this. Hourly fee lawyers, however, can increase billable hours by dilatory tactics. Settlements are therefore expected to take longer under hourly fees. This also shows empirically (Helland and Tabarrok 2003, p. $536 \mathrm{ff}$.).

With the same line of reasoning, we expect adjudication to take longer under hourly fees than under contingency fees. 


\subsection{Attorney Costs}

Contingency fee lawyers will charge a premium for the de facto financing and insurance services they provide, so that the expected hourly wages of contingency fee lawyers will exceed those of hourly fee lawyers (Brickman 1996, p. 270). This effect may be mitigated because contingency fee lawyers can use the contingent fee in the competition process, in order to attract more clients. However, it is an empirical question if the market for lawyers' services is competitive enough for this downward tendency. Another possible reason for a decrease in contingency fees is the fact that high-quality lawyers with a relative large success rate are able to ask for a lower percentage than lower quality lawyers. By charging a relative low fee, high quality lawyers can signal their quality, thereby attracting more clients. The danger, however, exists that clients view the low fee as a signal of low rather than high quality, in which case the signal would not be able to separate high quality and low quality lawyers (Brickman 2003, pp. 100-101).

\subsection{Principal-Agent Issues}

Implicit in the above analysis, we have already encountered a number of issues regarding the principal-agent relationship of clients and lawyers. The common ground of these issues is that the interests of lawyers and clients are not necessarily well-aligned. The client has an interest in winning the case against as low costs as possible, whereas the lawyer has an interest in earning an as high as possible fee.

This tension appeared in Section 4.3, where we argued that hourly fee lawyers have fewer incentives to provide the plaintiff with an unbiased assessment of the quality of their claim than contingency fee lawyers. Given the tendency of clients to choose contingency fees whenever there is a possibility of losing the case, a contingency fee lawyer may advise his client to take the case on a contingency fee basis, where in fact an hourly fee would have been better for the client (Kritzer 1998, p. 305). Also, given the fact that the lawyer can better assess the risks, he may negotiate a percentage that is higher than the case justifies (Halpern and Turnbull 1983, p. 14). Both possibilities for opportunistic behaviour are curtailed somewhat in rules governing fee negotiations in the United States and in the possibility of having the reasonableness of the fees evaluated by the court.

In Section 4.7 we discussed the effects on the duration of the case. The client often does not have adequate information to evaluate the amount of time an hourly fee lawyer claims is required for the case. This may induce the lawyer to allocate too many hours to the case. In Section 4.5 
we already saw that the opposite is true for a contingency fee lawyer, who is not expected to spend enough time on the case, given that he bears the full costs of additional effort, but only receives a fraction of the benefits thereof. An additional problem with hourly fee lawyers is that they could bill for more hours than they have actually put in. Contingency fees may reduce this moral hazard problem (Danzon 1983, Gravelle and Waterson 1993, Emons and Garoupa 2006).

\section{LEGAL EXPENSE INSURANCE}

\subsection{Introduction}

The last instrument in combating the financing problem discussed in this chapter is legal expense insurance. This instrument introduces an additional player into the analysis: the insurance company. Given that the interests of the insurer are not identical to those of the parties (plaintiff and defendant), and the interests of the lawyers involved are yet different, the full picture becomes rather complicated. This holds even more if one realizes that each player may possess different information. The multitude of principal-agent relationships opens many possibilities of strategic behaviour, which are dealt with in the following sections.

\subsection{Level of Suit}

Due to several reasons, legal expense insurances are expected to increase the level of suit. First, the insured plaintiff does not bear the full litigation costs, which increases the claim's expected value. Second, the insurance covers the plaintiff's risk, so that it induces risk-averse plaintiffs also to bring suit. Third, it solves a plaintiff's possible liquidity problem (Kirstein 2000, Van Velthoven and Van Wijck 2001).

An additional, more problematic reason why the level of suit may increase is formed by the typical informational problems of insurance contracts: moral hazard and adverse selection. These problems, if not adequately addressed, may cause the market for legal expense insurance to fail (Bowles and Rickman 1998, p.197). Due to adverse selection, mainly high-risks will take the insurance, increasing the likelihood that it will actually be used. Due to moral hazard, the insured may take fewer measures which could have avoided the conflict in the first place, again increasing the probability of using the insurance.

However, several instruments exist which allow insurance companies to confront both problems, such as risk diversification, exclusion of 
certain risks, deductibles et cetera. Empirical data from Germany and the Netherlands suggest that insurers are successful in this respect because, notwithstanding a rapid increase in the number of legal expense insurances, the number of claims per 100 policies remained practically constant in the Netherlands in the period 2000-2008 (Verbond van Verzekeraars 2005 , pp. 26-27 and 2009, pp. 94-95) and only increased by 4-8 per cent in Germany (Kilian and Regan 2004, p. 242. The period is not mentioned).

\subsection{Quality of the Claims}

Legal expense insurance could theoretically cause a flood of unmeritorious litigation, now the plaintiff does not bear the full costs of litigation. Claims could also be of low value, although the deductibles which are present in most policies reduce this problem.

However, the way in which insurances function in general reduces the scope for unmeritorious claims. In order for a risk to be insurable, the insurer needs a large enough volume of business, but he also needs to limit adverse selection (leaving moral hazard aside for the moment). The premiums collected should be high enough to cover the costs, but they should not be too high to be attractive for the potential insured. The higher the proportion of unmeritorious claims becomes, the higher the premiums have to be to cover the costs, inducing the good risks to terminate the insurance policy. Hence, in order to keep the insurance profitable, the insurer will pose limits on the coverage of unmeritorious claims. This can be done through, for example, only providing coverage if there is a reasonable chance of success (Rickman and Gray 1995, p.311, Killian 2003, p.46) and through the general obligation of good faith, which allows an insurer to deny coverage for groundless or unreasonable claims. Given that the insurer, being a repeat player, is better equipped to screen a case on its merits than the plaintiff himself, who is likely to be a one-shotter, this screening will likely increase the overall quality of the claims being brought.

Empirical research suggests that there is only limited difference in the value of claims issued by insured and uninsured litigants. Furthermore, the percentage of insured litigants winning their case is only 3 per cent higher than that of uninsured (Prais 1995, p. 439). This could be caused by more careful screening of the insurer, but it is not clear whether this indeed is the case.

\subsection{Drop Rate}

Insured plaintiffs are less likely to drop their case, now they do not bear the full costs themselves (Bowles and Rickman 1998, p. 197). However, 
the insurer can also influence the decision to drop a claim, by withdrawing coverage.

Two counteracting effects determine the overall impact of legal expense insurance on the drop rate. We do not have adequate data to determine the overall effect. The better screening of the insurer which we discussed in Section 5.3 results in fewer low-quality cases reaching the drop stage in the first place, leading to a lower drop rate (selection effect). On the other hand, if the insurer acquires new information suggesting a lower value of the claim, he may decide to withdraw coverage. As we have argued in Section 4.4, hourly fee lawyers on the contrary have few incentives to correctly advise their clients in the drop phase. This suggests that the drop rate may be higher with legal expense insurance than without it (screening effect).

\subsection{Settlement Rate}

Looking at the parties involved in the dispute, legal expense insurance covers their litigation costs and hence reduces the settlement surplus as well as the likelihood of settlement (Kirstein 2000, Van Velthoven and Van Wijck 2001). Also, the positive impact of risk aversion on the willingness to settle is removed by the insurance. However, the insurer still can benefit from settlement because it avoids the higher litigation costs. Hence, if allowed, the insurer may settle a case where the insured party would have preferred to go to trial.

If a plaintiff has legal expense insurance, his bargaining position is better than without the insurance, because he can more credibly threaten to go to trial. This implies that if a settlement is reached, the amount settled for is expected to be higher (Heyes, Rickman and Tzavara 2004, p. 109).

Empirical research in Germany suggests that settlement is discouraged by legal expense insurance, because $5-8$ per cent more litigants proceed to trial (Prais 1995, p. 439).

\subsection{Level of Adjudication}

The overall impact on the level of adjudication depends on the foregoing factors and cannot be predicted theoretically. According to Prais, a German study found that 'legal expenses insurance enabled the insured to issue proceedings more readily and to pursue those proceedings to judgment more tenaciously than if he did not have insurance', but this increase was 'only between 5 and 10 per cent' (Prais 1995, p. 439). 


\subsection{Duration of Claims}

Under the assumption that the (professional) insurer is better able to evaluate the quality of a claim than the (often non-professional) plaintiff, and given the better incentives of the insurer as compared to hourly fee lawyers, we expect low-quality claims to be dropped sooner if the plaintiff uses a legal expense insurance.

Regarding settlements, the better incentives for the insurer as compared to hourly fee lawyers again predict quicker settlements. This is confirmed empirically (Fenn et al. 2006, p. 26).

Regarding the duration of trial, two distinct principal-agent issues play a role. First, under an hourly fee system, an uninsured client has an incentive to monitor his attorney, given their diverging interests (see Section 4.9). If the client is insured, he no longer has this incentive. It is even in the immediate interest of the client if the lawyer spends more time on the case, if this improves the chances of success (Bowles and Rickman 1998, p. 200). The use of deductibles, co-payments and maximum coverage, as well as the possible increase in insurance premiums caused by the increase in lawyers fees, may however reduce this problem. Second, the insurer has an interest in limiting the duration of trial, but he has only limited options in doing so. If the insurer provides counsel, he may have incentives available to avoid delay. If the client has free choice of counsel, this no longer holds (also see Chapter 5 by Van Boom in this book). The superior information of the insurer as opposed to the insured, however, may still enable the former to better control the behaviour of the lawyer.

\subsection{Attorney Costs}

Finally, also regarding attorney costs, insurers face principal-agent issues. In countries where attorney fees are regulated (such as the German BRAGO system), attorney costs are more predictable so that costs are more controllable. Employing in-house lawyers is another way to control and reduce costs (Kilian 2003, p.42). The effect may be limited due to the right of the policyholder to choose its own counsel. Finally, insurers may invest in building a lasting relationship with a selected number of lawyers and law firms to handle their legal expense insurance cases. In such a relationship, costs are more controllable, due to the desire to maintain this relationship. 


\section{SUMMARY AND CONCLUSIONS}

In analyzing the impact of cost shifting, fee arrangements and legal expense insurance, economic literature addresses a multitude of effects. At the outset, improving private enforcement serves the goal of providing better behavioural incentives to the parties involved, so that they take better care, refrain from infringements, fulfil their contractual obligations, et cetera. Given that these incentives are often provided in the form of damages to be paid to the plaintiff, the question of to what extent civil law actually leads to compensation for the plaintiff obviously is relevant in this respect. The problem of rational apathy may frustrate private enforcement. Cost shifting, fee arrangements and legal expense insurance are possible solutions to this problem. In this Chapter, their impact on the different levels of the dispute resolution process is analyzed from an economic viewpoint.

Cost shifting influences the level of suit in several ways. If a plaintiff assesses his chances of winning to be relatively high, he will sue more often under the English Rule than under the American Rule. The same holds if the plaintiff expects to spend more on litigation than the defendant. However, risk aversion poses a stronger restriction on the level of suit under the English Rule, as does the fact that trial expenditures increase under this rule. The overall effect is unclear. Contingency fees are expected to increase the level of suit; because it solves the financing problem and it shifts the risk to a party who is better able to bear it. Legal expense insurance also is expected to increase the level of suit, because the plaintiff does not bear the costs, he is shielded from risk and his liquidity problem is solved. Furthermore, moral hazard and adverse selection, if not properly addressed, may increase the level of suit. Empirical research suggests that the increase is limited.

Cost shifting creates a selection effect towards higher-quality claims, because the lower the quality, the higher the probability of having to bear the other party's litigation costs. Risk aversion strengthens this effect. Empirical research corroborates these theoretical findings. Fee arrangements are also expected to increase the quality of the claims, because the lawyer acts as a gate keeper. This argument is supported by empirical research. The fear for meritless litigation that is often expressed when discussing contingency fees therefore seems unwarranted. The same fear is expressed regarding legal expense insurances but, here as well, the insurer will limit such claims, for example through merit tests or the general obligation of good faith. Hence, all three instruments have the potential to increase the quality of the claims.

All three instruments show two countervailing effects on the drop rate: 
on the one hand, the higher quality of the claims may lead to a lower drop rate because the weaker claims have not even been filed (selection effect). On the other hand, the cases that were filed may be screened better so that an increase in the drop rate is possible (screening effect). Empirical research regarding cost shifting suggests that the latter effect dominates there, whereas the former effect seems to dominate in fee arrangements. We do not know of empirical research regarding the overall effect in case of legal expense insurance.

The effect of cost shifting on the settlement rate again is determined by several factors. The English Rule increases litigation expenditure and hence the settlement surplus, which makes settling more attractive. Risk aversion increases this tendency. However, overestimation of the probability of success causes a counter-effect. Empirical research suggests that the latter effect dominates, so that cost shifting decreases the settlement rate. Fee arrangements and legal expense insurance, according to the recent theoretical and empirical literature, show the same tendency.

Given all the previous effects, the impact of the instruments on the level of adjudication cannot be predicted theoretically. Empirical research indicates that introduction of the English Rule leads to an overall decrease in adjudication, which is mostly caused by the higher drop rate. Contingency fees, on the other hand, tend to increase the level of adjudication. Legal expense insurance also leads to an increase, albeit a moderate one.

The total duration of the claim may be shortened by the English Rule, because it leads to an earlier drop and quicker settlements. However, adjudication may take longer because the trial expenditures tend to increase. Contingency fees also lead to a quicker drop, due to the superior information of the lawyer. Because a contingency fee lawyer does not gain from dilatory tactics, settlement and trial are expected to be finished quicker than under hourly fees. Legal expense insurance also leads to a quicker drop due to the better information of the insurer. Settlements will be quicker because the insurer does not gain by delay (different from an hourly fee lawyer). The trial will probably also be shorter, but the insurer only has limited possibilities of influencing the duration.

Finally, fee arrangements and legal expense insurance have an impact on the relationship between the different players (principals and agents). Contingency fees give the lawyer an own interest in winning the case, which better aligns his incentives with those of the client. However, he may advise contingency fees where an hourly fee would be more in the client's interest, and he may negotiate a too-high percentage. Legal expense insurance reduces the client's incentives to avoid conflicts from arising in the first place. If they arise, the client will start legal proceedings more readily and he has fewer incentives to monitor his lawyer. However, through 
instruments such as deductibles, co-payments and maximum coverage, insurers combat these problems. In their relation with lawyers, insurers try to control and reduce costs by employing in-house lawyers, or to invest in building a lasting relationship with selected lawyers.

It seems that cost shifting, fee arrangements and legal expense insurance are all able to lower the financial hurdles in pursuing a legal claim. The English Rule, however, still leaves the financial risk of losing the case with the plaintiff, and even increases the costs if the case indeed is lost. Contingency fees remove this risk altogether, and legal expense insurance reduces it to the deductible, co-payment or amount exceeding the maximum cover. This reduction of financial obstacles, combined with the selection effect towards higher quality claims, which all instruments show, has the potential to improve the behavioural incentives provided by the legal rules, because norm violators are better confronted with the consequences of their behaviour. This, in the economic analysis of law, is not regarded as merely a desirable side-effect of civil litigation, but as its main goal. The desire to improve the accessibility of civil litigation is hence not only important in the legal view focussing on fairness, but equally so in the welfare-oriented economic view.

\section{REFERENCES}

Bebchuk, Lucian A. (1996), 'A New Theory Concerning the Credibility and Success of Threats to Sue', Journal of Legal Studies, 25, 1-26.

Bebchuk, Lucian Arye and Andrew T. Guzman (1996), 'How Would You Like to Pay for That? The Strategic Effects of Fee Arrangements on Settlement Terms', Harvard Negotiation Law Review, 1, 53-64.

Bowles, Roger A. (1987), 'Settlement Range and Cost Allocation Rules', Journal of Law, Economics, \& Organization, 3, 177-184.

Bowles, Roger A. and Neil Rickman (1998), 'Asymmetric Information, Moral Hazard and the Insurance of Legal Expenses', The Geneva Papers on Risk and Insurance. Issues and Practice, 23, 196-209.

Braeutigam, Ronald, Bruce Owen and John Panzar (1984), 'An Economic Analysis of Alternative Fee Shifting Systems', Law and Contemporary Problems, 47, 173-185.

Brickman, Lester (1996), 'ABA Regulation of Contingency Fees: Money Talks, Ethics Walk', Fordham Law Review, 65, 247-335.

Brickman, Lester (2003), 'The Market for Contingent-Fee Financed Tort Litigation: Is it Price Competitive?', Cardozo Law Review, 25, 66-128.

Cooter, Robert D. and Daniel L. Rubinfeld (1989), 'Economic Analysis of Legal Disputes and Their Resolution', Journal of Economic Literature, 27, 1067-1097.

Clermont, Kevin M. and John D. Currivan (1978), 'Improving the Contingent Fee', Cornell Law Review, 63, 529-599.

Dana, James D. and Kathryn E. Spier (1993), 'Expertise and Contingent Fees: The 
Role of Asymmetric Information in Attorney Compensation', Journal of Law, Economics, \& Organization, 9, 349-367.

Danzon, Patricia M. (1983), 'Contingent Fees for Personal Injury Litigation', Bell Journal of Economics, 14, 213-224.

Danzon, Patricia, M. and Lee Lillard (1983), 'Settlement Out of Court: The Disposition of Medical Malpractice Claims', Journal of Legal Studies, 12, 345-377.

Daughety, Andrew F. (2000), 'Settlement', in: Boudewijn Bouckaert and Gerrit De Geest (eds), Encyclopedia of Law and Economics, Volume V. The Economics of Crime and Litigation, Cheltenham, UK and Northampton, MA, US: Edward Elgar, 95-158.

Di Pietro, Susanne, Theresa W. Carns and Pamela Kelley (1995), Alaska's English Rule: Attorney's Fee Shifting in Civil Cases, Anchorage, AK, US: Alaska Judicial Council, www.ajc.state.ak.us/reports/atyfee.pdf, accessed 27 July 2010.

Downs, Anthony (1957), An Economic Theory of Democracy, New York, NY, US: Harper and Row.

Emons, Winand (2007), 'Conditional Versus Contingent Fees', Oxford Economic Papers, 59, 89-101.

Emons, Winand and Nuno Garoupa (2006), 'The Economics of US-Style Contingent Fees and UK-Style Conditional Fees', Managerial and Decision Economics, 27, 378-385.

Faure, Michael G., Ton Hartlief and Niels J. Philipsen (2006a), Resultaatgerelateerde beloningssystemen voor advocaten. Een vergelijkende beschrijving van beloningssystemen voor advocaten in een aantal landen van de Europese Unie en Hong Kong, The Hague: Wetenschappelijk Onderzoeks- en Documentatie Centrum/Ministry of Justice, www.wodc.nl/images/1347_volledige_tekst_ tcm44-59425.pdf, accessed 27 July 2010.

Faure, Michael G., Ton Hartlief and Niels J. Philipsen (2006b), 'Funding of Personal Injury Litigation and Claims Culture. Evidence from the Netherlands', Utrecht Law Review, 2, 1-21, www.utrechtlawreview.org/publish/issues/200602/index.html, accessed 27 July 2010.

Fenn, Paul, Alastair Gray, Neil Rickman and Yasmeen Mansur (2006), The Funding of Personal Injury Litigation: Comparisons Over Time and Across Jurisdictions, London: Department for Constitutional Affairs, www.dca.gov.uk/ research/2006/02_2006.pdf, accessed 27 July 2010.

Gould, John P. (1973), 'The Economics of Legal Conflicts', Journal of Legal Studies, 2, 279-300.

Gravelle, Hugh S.E. (1998), 'Conditional Fees in Britain', in: Peter Newman (ed.), The New Palgrave Dictionary of Economics and the Law, London, UK: Macmillan Reference Limited and New York, NY, US: Stockton Press, 382-386.

Gravelle, Hugh S.E. and Michael Waterson (1993), 'No Win, No Fee: Some Economics of Contingent Legal Fees', The Economic Journal, 103, 1205-1220.

Halpern, P.J. and S.M. Turnbull (1983), 'Legal Fees Contracts and Alternative Cost Rules: An economic analysis', International Review of Law and Economics, 3, 3-26.

Hause, John C. (1989), 'Indemnity, Settlement, and Litigation, or I'll be Suing You', Journal of Legal Studies, 18, 157-179.

Hay, Bruce L. and Kathryn E. Spier (1998), 'Settlement of Litigation', in: Peter Newman (ed.), The New Palgrave Dictionary of Economics and the Law, 
London, UK: Macmillan Reference Limited and New York, NY, US: Stockton Press, 442-450.

Helland, Eric and Alexander Tabarrok (2003), 'Contingency Fees, Settlement Delay, and Low-Quality Litigation: Empirical Evidence from Two Datasets', Journal of Law, Economics, \& Organization, 19, 517-542.

Heyes, Anthony, Neil Rickman and Dionisia Tzavara (2004), 'Legal Expenses Insurance, Risk Aversion and Litigation', International Review of Law and Economics, 24, 107-119.

Hughes, James W. and Elizabeth Savoca (1997), 'Measuring the Effect of Legal Reforms on the Longevity of Medical Malpractice Claims', International Review of Law and Economics, 17, 261-273.

Hughes, James W. and Edward A. Snyder (1995), 'Litigation and Settlement Under the English and American Rules: Theory and Evidence', Journal of Law and Economics, 38, 225-250.

Hughes, James W. and Edward A. Snyder (1998), 'Allocation of Litigation Costs: American and English Rules', in: Peter Newman (ed.), The New Palgrave Dictionary of Economics and the Law, London, UK: Macmillan Reference Limited and New York, NY, US: Stockton Press, 51-56.

Katz, Avery W. (1987), 'Measuring the Demand for Litigation: Is the English Rule Really Cheaper?', Journal of Law, Economics, \& Organization, 3, 143-176.

Katz, Avery W. (2000), 'Indemnity of Legal Fees', in: Boudewijn Bouckaert and Gerrit De Geest (eds), Encyclopedia of Law and Economics, Volume V. The Economics of Crime and Litigation, Cheltenham, UK and Northampton, MA, US: Edward Elgar, 63-94.

Kilian, Matthias (2003), 'Alternatives to Public Provision: The Role of Legal Expenses Insurance in Broadening Access to Justice: The German Experience', Journal of Law and Society, 30, 31-48.

Kilian, Matthias and Francis Regan (2004), 'Legal Expenses Insurance and Legal Aid - Two Sides of the Same Coin? The experience from Germany and Sweden', International Journal of the Legal Profession, 11, 233-255.

Kirstein, Roland (2000), 'Risk Neutrality and Strategic Insurance', The Geneva Papers on Risk and Insurance. Issues and Practice, 25, 251-261.

Kobayashi, Bruce H. and Jeffrey S. Parker (2000), 'Civil Procedure: General', in: Boudewijn Bouckaert and Gerrit De Geest (eds), Encyclopedia of Law and Economics, Volume V. The Economics of Crime and Litigation, Cheltenham, UK and Northampton, MA, US: Edward Elgar, 1-26.

KPMG(1998), Conditional Fees - A Business Case, Report for the Lord Chancellor's Department.

Kritzer, Herbert M. (1997), 'Contingency Fee Lawyers as Gatekeepers in the Civil Justice System', Juridicature, 81, 22-29.

Kritzer, Herbert M. (1998), 'The Wages of Risk: The Return of Contingency Fee Legal Practice', DePaul Law Review, 47, 267-319.

Kritzer, Herbert M. (2002), 'Lawyer Fees and Lawyer Behavior in Litigation: What Does the Empirical Literature Really Say?', Texas Law Review, 80, 1943-1984.

Kritzer, Herbert M., William M.F. Felstiner, Austin Sarat and David M. Trubec (1985), 'The Impact of Fee Arrangement on Lawyer Effort', Law \& Society Review, 19, 251-278.

Landes, William M. (1971), 'An Economic Analysis of the Courts', Journal of Law and Economics, 14, 61-107. 
Landes, William M. and Richard A. Posner (1975), 'The private enforcement of law', Journal of Legal Studies, 4, 1-46.

Mause, Philip J. (1969), 'Winner Takes All: A Re-Examination of the Indemnity System', Iowa Law Review, 55, 26-55.

Miceli, Thomas J. (1994), 'Do Contingent Fees Promote Excessive Litigation?', Journal of Legal Studies, 23, 211-224.

Miceli, Thomas J. and Kathleen Segerson (1991), 'Contingent Fees for Lawyers: The Impact on Litigation and Accident Prevention', Journal of Legal Studies, 20, 381-399.

Miller, Geoffrey P. (1987), 'Some Agency Problems in Settlement', Journal of Legal Studies, 16, 189-215.

P'ng, Ivan P.L. (1983), 'Strategic Behavior in Suit, Settlement, and Trial', Bell Journal of Economics, 14, 539-550.

P'ng, Ivan P.L. (1987), 'Litigation, Liability, and Incentives for Care', Journal of Public Economics, 34, 61-85.

Polinsky, A. Mitchell and Daniel L. Rubinfeld (2002), 'A note on settlements under the contingent fee method of compensating lawyers', International Review of Law and Economics, 22, 217-225.

Posner, Richard A. (1973), 'An Economic Approach to Legal Procedure and Judicial Administration', Journal of Legal Studies, 2, 399-458.

Posner, Richard A. (2003), The Economic Analysis of Law, $6^{\text {th }}$ ed., New York, NY, USA: Aspen Publishers.

Prais, Vivien (1995), 'Legal Expenses Insurance', in Adrian A.S. Zuckerman and Ross Cranston (eds), Reform of Civil Procedure: Essays on 'Access to Justice', Oxford: Clarendon Press, 431-446.

Rickman, Neil (1995), 'The Economics of Cost-Shifting Rules', in Zuckerman, Adrian A.S. and Ross Cranston (eds), Reform of Civil Procedure: Essays on 'Access to Justice', Oxford: Clarendon Press, 327-345.

Rickman, Neil (1999), 'Contingent fees and litigation settlement', International Review of Law and Economics, 19, 295-317.

Rickman, Neil and Alastair Gray (1995), 'The Role of Legal Expenses Insurance in Securing Access to the Market for Legal Services', in Adrian A.S. Zuckerman and Ross Cranston (eds), Reform of Civil Procedure: Essays on 'Access to Justice', Oxford: Clarendon Press, 305-325.

Rosenberg, David and Steven Shavell (1985), 'A Model in Which Suits are Brought for Their Nuisance Value', International Review of Law and Economics, 5, 3-13.

Santore, Rudy and Alan D. Viard (2001), 'Legal fee restrictions, moral hazard and attorney rents', Journal of Law and Economics, 44, 549-572.

Schäfer, Hans-Bernd (2000), 'The Bundling of Similar Interests in Litigation. The Incentives for Class Action and Legal Actions taken by Associations', European Journal of Law and Economics, 9, 183-213.

Schwartz, Murray L. and Daniel J.B. Mitchell (1970), 'An Economic Analysis of Contingent Fee and Personal-Injury Litigation', Stanford Law Review, 22, $1125-1162$.

Shavell, Steven (1982), 'Suit, Settlement, and Trial: A Theoretical Analysis Under Alternative Methods for the Allocation of Legal Costs', Journal of Legal Studies, 11, 55-81.

Shavell, Steven (2004), Foundations of Economic Analysis of Law, Cambridge, Massachusetts: The Belknap Press of Harvard University Press.

Snyder, Edward A. and James W. Hughes (1990), 'The English Rule for Allocating 
Legal Costs: Evidence Confronts Theory', Journal of Law, Economics, \& Organization, 6, 345-380.

Thomason, Terry (1991), 'Are Attorneys Paid What They're Worth? Contingent Fees and the Settlement Process', Journal of Legal Studies, 20, 187-223.

Van den Bergh, Roger J. and Louis T. Visscher (2008), 'Optimal Enforcement of Safety Law', in: Richard D. de Mulder (ed.), Mitigating Risk in the Context of Safety and Security. How Relevant is a Rational Approach?, Rotterdam: Erasmus University Rotterdam, 29-62.

Van Velthoven, Ben C.J. and Peter W. van Wijck (2001), 'Legal Cost Insurance and Social Welfare', Economics Letters, 72, 387-396.

Verbond van Verzekeraars (2005), Verzekerd van Cijfers. Dutch Insurance Industry in Figures, www.verbondvanverzekeraars.nl/Cijfers/Verzekerd van Cijfers/ Cijfers 2005.aspx. Accessed on 27 July 2010.

Verbond van Verzekeraars (2009), Verzekerd van Cijfers. Dutch Insurance Industry in Figures, www.verbondvanverzekeraars.n1/UserFiles/File/cijfers/VvC2009. pdf, accessed 27 July 2010.

Williams, Philip L. and Ross A. Williams (1994), 'The Cost of Civil Litigation: An Empirical Study', International Review of Law and Economics, 14, 73-86. 